Maja Mijatov*, Aleksandra S. Dragin, Vladimir Stojanović, Anđelija Ivkov Džigurski, Milena Nedeljković Knežević, Kristina Košić

University of Novi Sad, Faculty of Sciences, Department of Geography, Tourism and Hotel Management, Serbia

\title{
Ethical Code and its Influence on the Employees' Perception of Organizational Social Responsibility
}

\author{
DOI: 10.7595/management.fon.2021.0021
}

\begin{abstract}
:
Research Question: The research is oriented towards determining implementation of the ethical code in hotels, located within the National Park of Serbia, Kopaonik, and its effects on perception of organisational social responsibility dimensions among the hotel employees. Motivation: Application of the ethical code is the first step towards clarifying the standards of acceptable business practices to various stakeholders of the organization, including the employees (Supanti, Butcher, \& Fredline, 2015). In this regard, this research is focused on identifying the manners in which the application and content of the ethical code can affect the perception of social responsibility. Idea: The ethical code and public discussion with employees on topics in the field of ethics might affect the perception of employees regarding the organisational social responsibility. In this way, it could contribute to development and strengthening of employees' awareness of the problems of the wider community, as well as business activities that might endanger or help society to overcome these specific problems. Besides, the idea was to research into the implementation of these ethical issues in the business operations in the National Park. Data and Tools: The survey research was conducted within popular tourism destination in Serbia, Kopaonik, on the sample of 211 hotel employees. Findings: The research results show that application of the ethical code shapes the perception of Legal and Economic dimension of organisational social responsibility. Also, the research results indicate the fact that the form in which the ethical code is applied shapes the employees' perception of philanthropic, legal, economic and ethical dimensions of organisational social responsibility. In addition, results of the research indicate that the usage of the ethical code, as a means of information, shapes the employees' perception of legal and ethical dimension of organisational social responsibility, while the organization of meetings on ethical issues shapes the employees' perception of philanthropic dimension of organisational social responsibility. Contribution: The research results might have scientific and practical application as guidelines for improving the business performance in the operation of numerous organizations in the field of tourism, primarily in hotels, but also among the others in the tertiary sector.
\end{abstract}

Keywords: ethical code, organizational social responsibility, employees, hotel, Kopaonik

JEL classification: D79, D91, J53, J8, M12, M54, Z32, Z39.

\section{Introduction}

Contemporary business conditions raised the interest of academics and practitioners related to implementation of the ethical code and organizational social responsibility activities within the different business sectors. In addition, another important characteristic of contemporary business is related to the necessity of defining the standards of behaviour within a specific business environment. The organization could clarify the standards of acceptable business behaviour to internal and external stakeholders by adopting and implementing the ethical code, which can contribute to raising the awareness and commitment related to responsible practice of all business stakeholders, including the employees (Paine, Deshpande, Margolis, \& Bettcher, 2015; Saha, Cerchione, Singh, \& Dahiya, 2020). 
In previous decades, numerous organizations were oriented towards establishing the rules of acceptable business behaviour. However, the main role of these rules in shaping the organizational culture is different nowadays in comparison with the previous decades. Thus, the main focus of the ethical code is reoriented from writing the comprehensive rules towards aligning the organizational rules with values of each business environment, in order to bring prescribed rules closer to employees. These changes represent a consequence of the fact that investors, customers and other stakeholders are increasingly interested in cooperation with organizations with high ethical standards and commitment to organizational social responsibility, which is the main reason why management of different organizations increasingly focuses their efforts on ethical issues, as important aspects of organizational culture (Yidong \& Xinxin, 2013; Frye, 2020). Accordingly, this research is oriented towards identifying the impact of the ethical code on the employees' perception of organizational social responsibility within hotels located at Kopaonik, that are operating within the territory of the National Park, which additionally imposes the necessity of implementing the responsible business operations. It is also important to consider the fact that these hotels are located within a popular centre of winter tourism in Serbia, with a constant need for employing the seasonal workforce, which makes this destination an interesting business environment for researching the human resources, together with their perceptions of organizational social responsibility and related ethical issues.

\section{Literature Review}

\subsection{Ethical code}

Ethical code is one of the most developed and represented components of normative systems for managing the business ethics worldwide (Schwartz, 2001). Previous studies showed that ethical code might shape the employees' behaviour (Adams, Tashchinan, \& Shore, 2001; Malloy \& Agarwal, 2003; Hassan, Pandey, \& Pandey, 2020), according to the fact that it could be considered as a manual that might help employees to make a difference between acceptable and unacceptable behaviour within specific business environment, on the basis of providing a guidance for ethical issues. Thus, ethical code could help employees in better understanding of organizational values. It could also influence alignment of organizational and employees' attitudes throughout performing their business tasks. Besides that, ethical code could help employees from different cultural and social backgrounds in their adaptation to business conditions across different geographic and cultural settings (Schwartz, 2001), which is particularly important for the tourism sector, due to intensive employment of aforementioned seasonal workforce. However, the impact of the ethical code on the employees' behaviour might also depend on the manner in which organizations use this instrument. Therefore, one of the main tasks of this research was oriented towards identifying the level of implementation, as well as the form of the ethical code in hotels located at Kopaonik, including the manner in which its content might shape the employees' perceptions of organizational social responsibility within this destination, with the main aim of gaining the data that could help hotel management in improving their relations towards the employees, due to the fact that employees could shape the quality of provided service, as well as the overall business success.

\subsection{Organizational social responsibility}

Numerous organizations consider their role in society, which is the main reason of increased orientation towards implementation of standards related to organizational social responsibility within their businesses (Lichtenstein, Drumwright, \& Bridgette, 2004; Stojanovic-Aleksic \& Boskovic, 2017; Fernandez Gago, Cabeza Garcia, \& Godos Diez, 2020), on the basis of applying the activities used for improving the wellbeing of local or wider community, beyond the organizational interests and often beyond responsibilities prescribed by the law (McWilliams \& Siegel, 2001; Kong, Antwi Adjei, \& Bawuah, 2020). As the first one who proposed multidimensionality of organizational social responsibility, Carroll (1979) noted that social activities of organization could be divided into several dimensions, including the ethical, philanthropic, economic and legal responsibility. Thus, ethical responsibility is related to organizational activities that are not prescribed by the law, but are expected by society, while philanthropic responsibility includes activities that go even beyond the social expectations. The economic dimension is related to socio-economic or financial aspects of concrete organization, defined from operational perspective. Nevertheless, organizational social responsibility activities are often shaped by the regulatory requirements, as it is indicated by a definition of Legal dimension of organizational social responsibility (Carroll, 1979; Carroll \& Shabana, 2010). These categories might provide a comprehensive report on the construction of organizational social responsibility, 
while they could also serve as reminders on motives, or even concrete organizational social responsibility practices that could be categorized into one of the aforementioned categories (Carroll, 1979; Carroll \& Shabana, 2010).

\subsection{Correlation between the ethical code and the concept of organizational social responsibility}

Ethical code may encourage implementation of organizational social responsibility if its content is transparent to employees, as well as if the organization initiates discussions related to ethical issues within the business environment. In this way, or more precisely on the basis of discussions with employees who are also the members of particular local community or wider society, organizations can become aware of problems outside the organizations and within the environment in which they operate (Trong Tuan, 2012). Management support is also valuable in accepting and implementing the organizational social responsibility activities. Therefore, it is important to provide the managers' understanding of all potential benefits that organizational social responsibility could provide, in order that they enable the development of this feeling among the employees within the lower organizational levels. It is also important that employees, based on their personal experience, may notice that organizations are oriented towards encouraging organizational values that support social responsibility (Supanti, Butcher, \& Fredline, 2015). Thus, employees might feel more secure in organizations with organizational social responsibility activities, while such sense of security might even reduce their intentions to leave the organization (Vitaliano, 2010). In respect to that, this research is oriented towards identifying the manner in which standards of acceptable business behaviour were defined, as well as the manner in which they were represented to employees within the service industry, on the sample of hotels in the leading ski centre of Serbia. Finally, the main aim of this research is related to identifying the employees' perception of the concept of organizational social responsibility, through ethical and other dimensions, by applying the Carroll's model, given its high representation in foreign research (Matten \& Moon, 2008; Scherer \& Palazzo, 2011; Orlitzky, Schmidt, \& Rynes, 2003), as well as neglected usage in previous research conducted in Serbia.

\section{Methodology}

\subsection{Instrument}

This research was conducted on the basis of the questionnaire that was formed after the literature review of previous research related to the ethical code and organizational social responsibility. The entire content of the questionnaire could be divided into several sections. The first section covered the questions related to general information on whether there is the ethical code within hotels located at Kopaonik, as well as in which form the ethical code is implemented and represented to hotel employees.

The second section of questions was related to organizational social responsibility, according to the aforementioned Carroll's Model of Social Performances (Carroll, 1979; Carroll \& Shabana, 2010), based on the previously mentioned understanding that organizational social responsibility contains four dimensions: economic, legal, ethical and philanthropic. Also, Carroll's research, conducted in 1979 (Carroll, 1979), with precise definition of the Model of Social Performances, is cited for 12,846 times in the existing literature, according to the Google Scholar's basis [https://scholar.google.com / scholar? cites = $3879112735652133758 \&$ as_sdt $=2005 \&$ sciodt $=0.5 \& \mathrm{hl}=$ en]. The research conducted concerning Kopaonik also started from the abovementioned four dimensions of organizational social responsibility that were previously identified and explained in details within the research conducted by Mijatov, Blesic and Dragin (2018).

The third section of the questionnaire covered the questions related to the content and the manner in which the ethical code is considered and applied within the organization, based on the 11 items formed for the purpose of researching the ethical issues in tourism of Serbia (Dragin, Jovanovic, Mijatov, Majstorovic, \& Dragin, 2019a; Jovanovic, Mijatov, Dragin, Simat, \& Majstorovic, 2019b). This part of the research covered the employees' attitudes regarding the consideration and application of the ethical code within their hotels as a source of information, educational resource, a guidance for protection of the employees, as well as regarding their attitudes on the level to which the ethical code is related to products or services, customers, employees, competition, marketing, or other aspects (where respondents had the opportunity to provide additional answers). Finally, employees were asked to express their attitudes on transparent discussions 
about ethics and ethical dilemmas within their organization, as well as regarding the frequency of organizing the meetings about ethics and ethical dilemmas.

\subsection{Sample and data collecting procedure}

The survey research was conducted at Kopaonik in 2015. Hotels within the Kopaonik area are characterized by $25 \%$ of the long term permanent employees, who are well acquainted with the researched business environment. On the other hand, it is also important to indicate that $75 \%$ of the other employees, those employed during the season, also spend several years in the same business environment. The praxis of the management of the surveyed hotels, which is primarily oriented towards employing those individuals who already worked within the same business environment during the previous seasons, resulted in the fact that $55 \%$ of the respondents have up to five years of working experience in the hotels at Kopaonik (primarily within the newer hotels that have been in operation for less than five years), or even longer (emphasizing $20 \%$ of those employed between six and ten years and $10 \%$ of those employed between 11 and 15 years, mainly within older hotels within this destination).

Responses were collected on the basis of the survey research, by using the standard pen and paper procedure. Respondents were informed regarding the anonymity of the research. The survey research included the employees who showed the interest in participating, so the sample might be considered as a convenience. Before starting with the survey research, individuals employed within the supervisory positions were contacted in order that they should explain the main idea of the research to their employees. Besides that, supervisors also participated in the survey research as the respondents. With their help, a sample of 211 respondents was collected (obtaining the $70.59 \%$ of entire hotel facilities within Kopaonik). More precisely, the authors distributed 300 questionnaires to the respondents and 236 of them returned the questionnaires. However, part of returned questionnaires was not completely filled in, which is the main reason why 25 questionnaires were excluded from the final data analysis. Collected data were analysed in SPSS 17.0 (Software Package for Social Sciences, 17.0), by using the following statistical methods: descriptive statistics, exploratory factor analysis (for grouping the items related to organizational social responsibility into a smaller number of factors, as part of the study conducted by Mijatov, Blesic and Dragin (2018), t-test and analysis of the variance (for determining the influence of implementation and form of the ethical code on the employees' perception of organizational social responsibility) and regression analysis (general linear models - continuous variables, for determining the influence of the content and the manner in which the ethical code is considered and applied within the organization on the employees' perception of dimensions of organizational social responsibility).

\section{Results}

The research results related to implementation of the ethical code point to the fact that as many as $78.2 \%$ of the respondents indicated that they are employed within hotels with implemented ethical code. However, $19 \%$ of the respondents do not know if the ethical code is represented within the hotel they work with, while only $2.8 \%$ of them indicated that the ethical code is not represented within the business environment of hotel where they are employed. Furthermore, $43.1 \%$ of the respondents indicated that the ethical code is represented in a verbal form within their business environment, while $34.6 \%$ of the respondents stated that the ethical code is represented in a written form. However, $22.3 \%$ of them do not know in which form the ethical code is represented within their business environment. In general, the research results indicate that the ethical code is not sufficiently transparent within hotels at Kopaonik, due to the fact that it is represented in a written form even within hotels whose employees stated that ethical code is represented exclusively in a verbal form within their business environment, which points to their insufficient transparency.

Furthermore, the research results of the analysis of the variance indicates that there are significant differences in the employees' perception of legal $(F=3,178 ; p<0.05)$ and economic dimensions of organizational social responsibility $(F=4,137 ; p<0.05)$, on the basis of the implementation of the ethical code within hotels included in the study. The research results represented within Figure 1 point to the employees' perception of the legal dimension of organizational social responsibility based on the representation of the ethical code within the business environment. Thus, employees' perception of the legal dimension of organizational social responsibility is higher among the respondents in hotels with an implemented ethical code, comparing to the employees' perception in hotels where respondents stated that there is no ethical code within their business environment, but also in comparison with those who stated that they were not sure whether the ethical code was implemented within hotels they work for. 


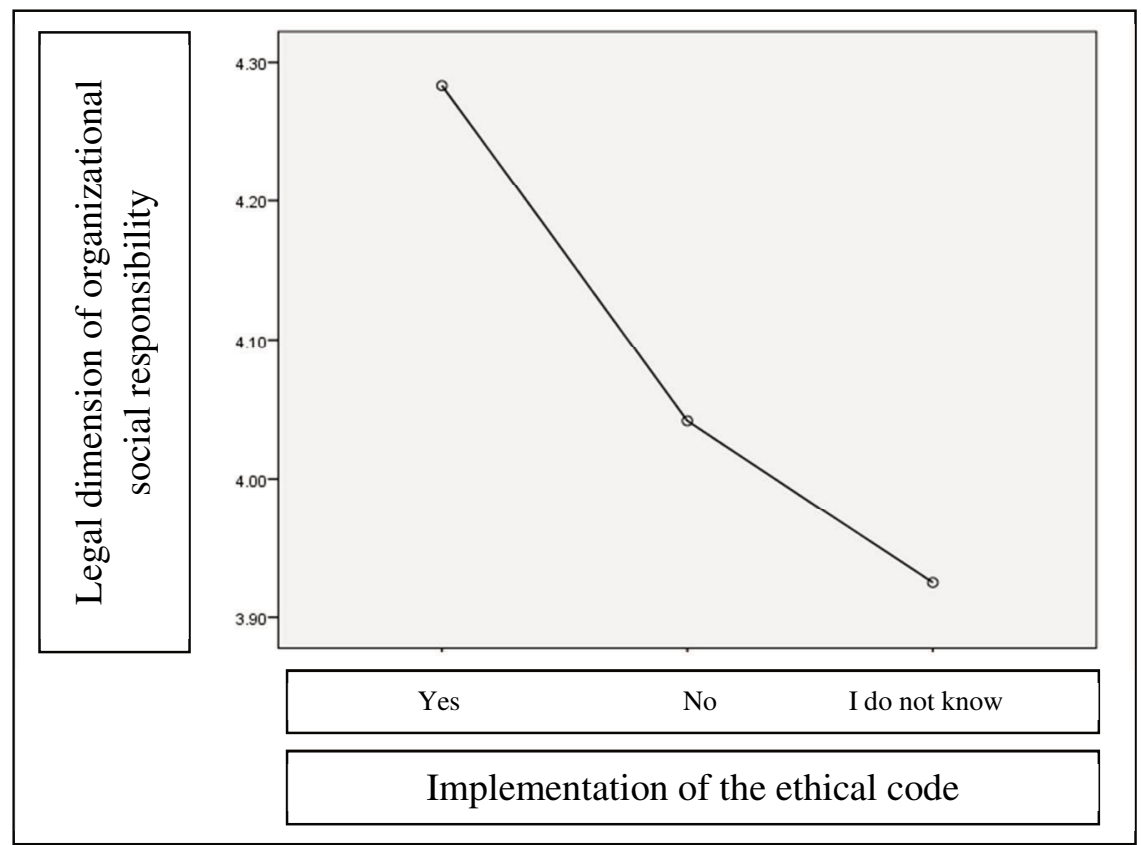

Figure 1: Implementation of the ethical code and the employees' perceptions of legal dimension of organizational social responsibility $(F=3,178 ; p<0.05)$

(Source: Research Results)

Furthermore, employees' perception of the economic dimension of organizational social responsibility is higher among the respondents in hotels with implemented ethical code, compared to the employees' perception of those who do not know if the ethical code exists within their business environment. These research results are represented in the Figure 2.

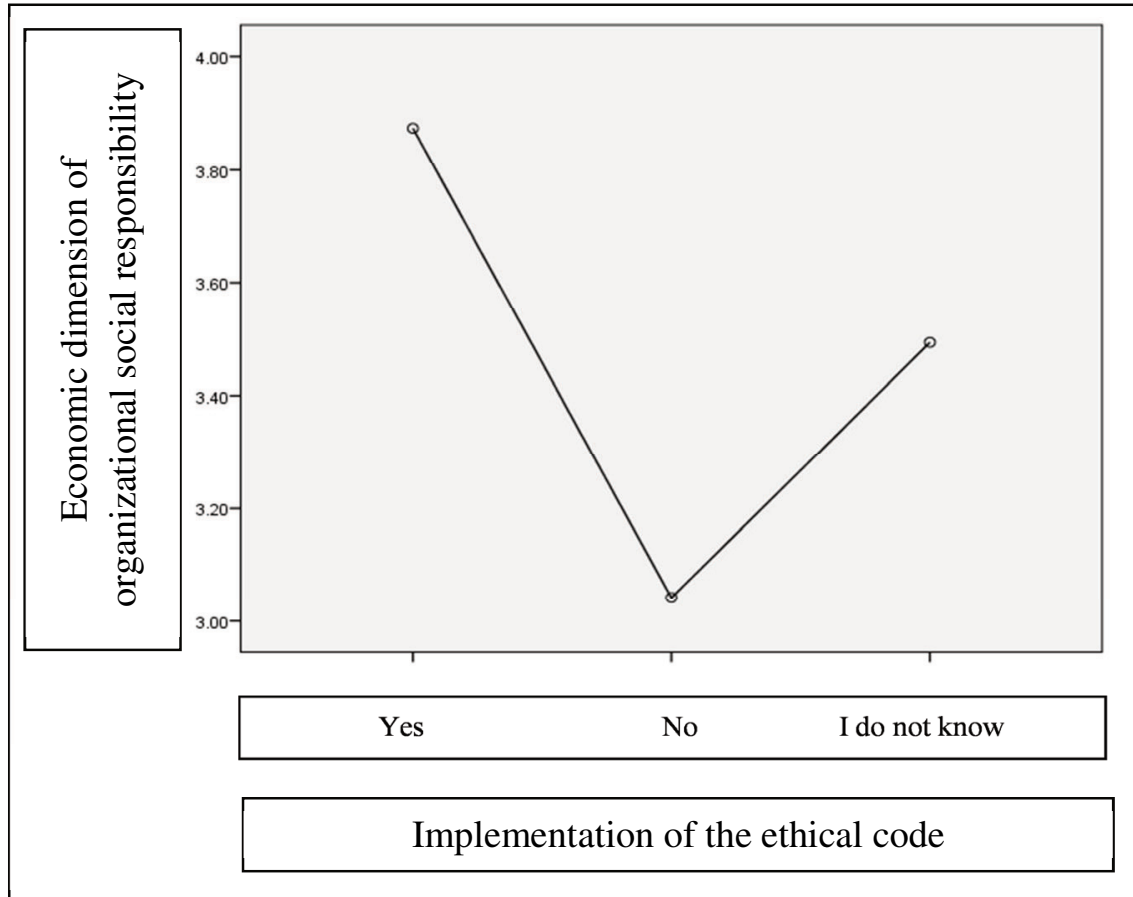

Figure 2: Implementation of the ethical code on the employees' perceptions of economic dimension of organizational social responsibility $(F=4,137 ; p<0.05)$

(Source: Research Results) 
The research results of t-test indicated that there are significant differences in the employees' perception of all dimensions of organizational social responsibility between the respondents employed within hotels where the ethical code is implemented in a verbal form and those employed within hotels where the ethical code is implemented in a written form, which is represented within Table 1. Thus, a higher perception of philanthropic $(t=-2,506 ; p<0.05)$, legal $(t=-2,932 ; p<0.01)$, economic $(t=-4,223 ; p<0.01)$ and ethical dimension of organizational social responsibility $(t=-2.217 ; p<0.05)$ is indicated by the respondents who are aware that the ethical code is represented in the written form within hotels they work for.

Table 1: Dimensions of organizational social responsibility according to the form of implementation of the ethical code

\begin{tabular}{|c|c|c|c|}
\hline $\begin{array}{c}\text { Dimensions of organizational social } \\
\text { responsibility }\end{array}$ & $\begin{array}{l}\text { Verbal } \\
\text { (M) }\end{array}$ & Written (M) & T-value \\
\hline $\begin{array}{l}\text { Philanthropic dimension of organizational social } \\
\text { responsibility }\end{array}$ & 3.01 & 3.44 & $-2.506^{\star \star}$ \\
\hline $\begin{array}{l}\text { Legal dimension of organizational social } \\
\text { responsibility }\end{array}$ & 4.12 & 4.49 & -2.932 * \\
\hline $\begin{array}{c}\text { Economic dimension of organizational social } \\
\text { responsibility }\end{array}$ & 3.61 & 4.22 & $-4.223^{*}$ \\
\hline $\begin{array}{c}\text { Ethical dimension of organizational social } \\
\text { responsibility }\end{array}$ & 3.87 & 4.16 & $-2.217^{* *}$ \\
\hline
\end{tabular}

Note: *. Correlation is significant at the .01 level.

**. Correlation is significant at the .05 level. Source: Research Results

On the other hand, the implementation of the multivariate General Linear Models points to the fact that two out of 11 items related to the content and the manner in which the ethical code is considered and implemented within the organization have shaped the employees' perception of dimensions of organizational social responsibility. Thus, consideration of the ethical code as a source of information shaped the employees' perception of two dimensions of organizational social responsibility: legal and ethical (Table 2). Thus, employees' perception of the legal dimension of organizational social responsibility is higher among the respondents employed within hotels where the ethical code is always considered as a source of information. The same results are recorded in the case of the employees' perception of ethical dimension of organizational social responsibility. Also, the lowest perceptions of legal and ethical dimensions of organizational social responsibility are recorded among the respondents employed within hotels where the ethical code is never considered as a source of information.

Finally, the frequency of organizing the meetings about ethics and ethical dilemmas has also shaped the employees' perception of the philanthropic dimension of organizational social responsibility. Thus, the strongest perception of the philanthropic dimension of organizational social responsibility is recorded among the respondents employed in hotels where such meetings are always organized, while it is the lowest among the respondents employed in hotels that failed to organize the meetings on ethical issues.

Table 2: General Linear Models, organizational social responsibility

\begin{tabular}{|c|c|c|c|c|c|}
\hline \multirow{2}{*}{\multicolumn{2}{|c|}{$\begin{array}{c}\text { Aspects that could shape the employees' } \\
\text { perception of organizational social } \\
\text { responsibility }\end{array}$}} & \multicolumn{4}{|c|}{$\begin{array}{l}\text { Dimensions of organizational social responsibility } \\
\text { (Mean Values) }\end{array}$} \\
\hline & & $\begin{array}{l}\text { Philanthropic } \\
\text { dimension }\end{array}$ & $\begin{array}{c}\text { Legal } \\
\text { dimension }\end{array}$ & $\begin{array}{l}\text { Economic } \\
\text { dimension }\end{array}$ & $\begin{array}{c}\text { Ethical } \\
\text { dimension }\end{array}$ \\
\hline $\begin{array}{l}\text { Ethical code is } \\
\text { considered as a } \\
\text { source of } \\
\text { information. } \\
(\mathrm{M}=3.29)\end{array}$ & $\begin{array}{r}\text { Never (1) } \\
\text { Rarely (2) } \\
\text { Sometimes (3) } \\
\text { Often (4) } \\
\text { Always (5) }\end{array}$ & & \begin{tabular}{|c|}
3.29 \\
3.94 \\
4.06 \\
4.48 \\
4.75 \\
$5.29^{\star *}$
\end{tabular} & & $\begin{array}{c}2.96 \\
3.58 \\
3.80 \\
4.22 \\
4.68 \\
5.90^{\star \star}\end{array}$ \\
\hline $\begin{array}{l}\text { Meetings about } \\
\text { ethics and } \\
\text { ethical dilemmas } \\
\text { are organized } \\
\quad(\mathrm{M}=2.95)\end{array}$ & $\begin{array}{r}\text { Never (1) } \\
\text { Rarely (2) } \\
\text { Sometimes (3) } \\
\text { Often (4) } \\
\text { Always (5) }\end{array}$ & $\begin{array}{l}2.44 \\
2.46 \\
3.33 \\
3.48 \\
4.21 \\
.25^{*}\end{array}$ & & & \\
\hline
\end{tabular}




\section{Discussion}

The research results point to the fact that the presentation of the ethical code in hotels has shaped the employees' perception of the legal and economic dimensions of organizational social responsibility. Thus, stronger perceptions of both dimensions are recorded among the employees who stated that the ethical code is implemented within hotels they work with, as it was expected. Also, a stronger perception of all dimensions of organizational social responsibility is indicated by the respondents who state that the ethical code within the hotel they work with is represented in a written form, so it seems that the ethical code might contain certain parts that are related to organizational social responsibility. The research results are in line with the findings of Trong Tuan (2012), who indicates that ethical code can strengthen the employees' perception of organizational social responsibility if it is transparent and if it points to the problems that might exist outside the organizational framework. The basic points expressed within the ethical code reflect the ethical principles that emerged as a need for solving the problems that might exist in almost all social communities, so it is imperative for managers and business owners to ensure that their business activities are in line with the ethical code, but also with wider social expectations (Hassan, 2007; Huimin \& Ryan, 2011; Paine et al., 2005; Yaman \& Gurel, 2006; Abugre \& Anlesinya, 2020; Peifer \& Newman, 2020; Sigurdsson \& Candi, 2020).

Ethical codes of successful organizations are usually based on several principles. The principle of committee refers to the fact that management and employees are considered to be executors of specific organization, responsible for protection of organizational resources, as well as for performance of job-related duties on behalf of the organization. This principle requires the employees' conscientiousness, carefulness and efforts in order to protect tangible and intangible assets of organization. The second principle is reliability. The classic type of breaking the reliability principle includes non-compliance of a given promise or signed contract. The next principle is related to transparency, whose basic ideas of honesty and respect for truth are treated as ethical imperatives. Furthermore, the principle of respect is a starting point of almost all ethical rules, while it leads directly to protection of health, safety, freedom of expression and protection of privacy within the business environment, with disapproval of humiliation and other forms of offenses that could violate basic human rights. It also involves positive efforts oriented towards development of human resources, while it often involves expressed altruism towards those who are disabled or particularly vulnerable in some other way. However, the principle that mostly emphasizes the connection between business ethics and organizational social responsibility is related to the principle of the active member of society and the fact that ethical codes could vary in a degree to which organizations feel they should be active in addressing the current social issues. Members of society have certain responsibilities for maintaining the common resources, such as natural environment, public spaces, but also the entire community. Therefore, organizations as active members of a society are also expected to repair the damage caused to the common resources as a consequence of their business operations. Beyond the basic idea, the principle of the active member of the society also implies a willingness of the organization to deal with the public social issues, which implies additional contribution on the basis of investing in charities, supporting community or helping in addressing the broader-scale social problems. Finally, the principle of responsibility implies a willingness to cooperate with other parties that might be threaten by organizational activities (Paine et al., 2005). All of these principles should be more actively included in ethical codes of hotels located at Kopaonik, due to the fact that they do not sufficiently indicate the necessity of operating in accordance with organizational social responsibility in their current form.

In case of shaping the employees' perception of organizational social responsibility within Kopaonik, the research results point out that content of the ethical code and the manner of its consideration and implementation shape the employees' perception. Thus, the consideration of the ethical code as a source of information shaped the employees' perception of Legal and Ethical dimensions of organizational social responsibility. In both dimensions, it could be noticed that employees' perceptions increase along with the increase in using the ethical code as a source of information. Therefore, employees will show express awareness of the fact that the hotel is oriented towards complying with the legal aspects of the business if they notice that hotels they work with use the ethical code as a source of information, since the ethical code itself is a legal act that organizations, hotels in this case, need to apply in their business operations. The same case with the Ethical dimension of organizational social responsibility indicate that the ethical code might clarify to the employees what kind of working conditions they can expect in Kopaonik hotels and what kind of relations between the employer, employees and customers are encouraged, by establishing the openness and collaboration between the previously mentioned stakeholders.

Furthermore, the frequency of organizing the meetings about ethics and ethical dilemmas in hotels located at Kopaonik shaped the employees' perception of Philanthropic dimension of organizational social responsibility. Thus, the perception of the philanthropic dimension of organizational social responsibility 
increases along with the frequency of organizing such meetings in hotels. Therefore, throughout these meetings, one of the topics is related to hotel's orientation towards helping the wider community. Thus, employees' awareness of philanthropic dimension of organizational social responsibility will increase in a situation when they notice increased hotels' efforts oriented towards improving the business reputation on the basis of the volunteer activities aimed at members of society that need help.

The research results support the fact that the ethical code and public discussion with employees about ethics and ethical dilemmas might shape the employees' perceptions of organizational social responsibility (Supanti et al., 2015; Trong Tuan, 2012; Vitaliano, 2010; McCandless \& Ronquillo, 2020; Wang, Xu, \& Wang, 2020). Accordingly, the research results could contribute to developing and raising the employees' awareness regarding the problems of the wider community, as well as regarding the business activities that might reduce these problems.

\section{Conclusion}

Contemporary business conditions are becoming more demanding, which is the main reason why organizations are increasingly confronted with the fact that ethical principles should be an integral part of their business operations. Employees' behaviour within the business environment could be reflected on overall business performance, especially within the service industry, which is characterized by a high level of interaction between the customers and service providers. Accordingly, organizations should implement the ethical code, as a form of normative systems for shaping the employees' behaviour in order to achieve specific business goals.

If employees perceive that they are part of the organization with balanced business operations and wider social needs, their job satisfaction may increase, simultaneously with the level of their organizational trust, together with the level of their service orientation, as important non-financial indicators of business performances and important aspects of achieving financial business success. Accordingly, the results of this research may find a practical application, due to the fact that they could serve as guidelines for improving the business performance throughout the business operations of numerous organizations in the field of tourism, primarily in hotels, but also in others within the tertiary sector. Besides, it is important to keep in mind that appropriate measures for raising the awareness of the employees regarding the social responsibility of organisations are still not formed and implemented at the national level (e.g., sorting the waste in hotels, various actions of employees in the local environment, education of employees, etc.), which additionally increases the possibility of practical implementation of the gained results.

\section{Acknowledgements}

The authors acknowledge the financial support of the Ministry of Education, Science and Technological Development of the Republic of Serbia (Grant No. 451-03-9/2021-14/ 200125).

\section{REFERENCES}

[1] Adams, J.C. Tashchinan, A., \& Shore, T.H. (2001). Codes of ethics as signals for ethical behavior. Journal of Business Ethics, 29, 199-211. DOI: 10.1023/A:1026576421399.

[2] Mijatov, M., Blesic, I., \& Dragin, A. (2018). Corporate social responsibility and service orientation of hotel employees. Teme, XLII, 2, 441-458.

[3] Dragin, A., Jovanovic, T., Mijatov, M., Majstorovic, N., \& Dragin, V. (2019a). Types and factors of ethical climate perception in Serbian tourism industry. Journal of East European Management Studies, Special Issue, 63-98.

[4] Jovanovic, T., Mijatov, M., Dragin, A., Simat, K., \& Majstorovic, N. (2019b). Identification of predictors' effects on perceiving the ethical climate and job satisfaction within Serbian tourism industry. Journal of Management and Organization, published online by Cambridge University Press: 21 May 2019. DOI: 10.1017/jmo.2019.36.

[5] Carroll, A.B. (1979). A three dimensional conceptual model of corporate social performance. Academy of Management of Review, 4(4), 497-505. DOI: 10.5465/amr.1979.4498296.

[6] Carroll, A.B., \& Shabana, K.M. (2010). The business case for corporate social responsibility: A review of concepts, research and practice. International Journal of Management Reviews, 12(1), 85-105. DOI: 10.1111/j.1468-2370.2009.00275.x.

[7] Fernandez Gago, R., Cabeza Garcia, L., \& Godos Diez, J. L. (2020). How significant is corporate social responsibility to business research? Corporate Social Responsibility and Environmental Management, 27(4), 1809-1817. DOI: 10.1002/csr.1927. 
[8] Frye, E. Y. (2020). The role of HRD in influencing ethical behavior and corporate social responsibility within organizations. New Horizons in Adult Education and Human Resource Development, 32(2), 62 66. DOI: 10.1002/nha3.20277.

[9] Hassan, A. (2007). Human resource development and organizational values. Journal of European Industrial Training, 31(6), 435-448. DOI: 10.1108/03090590710772631.

[10] Hassan, S., Pandey, S., \& Pandey, S. K. (2020). Should managers provide general or specific ethical guidelines to employees: Insights from a mixed methods study. Journal of Business Ethics, 1-18. DOI: 10.1007/s10551-020-04442-3.

[11] Huimin, G., \& Ryan, C. (2011). Ethics and corporate social responsibility - An analysis of the views of Chinese hotel managers. International Journal of Hospitality Management, 30, 875-885. DOI: 10.1016/j.ijhm.2011.01.008.

[12] Kong, Y., Antwi Adjei, A., \& Bawuah, J. (2020). A systematic review of the business case for corporate social responsibility and firm performance. Corporate Social Responsibility and Environmental Management, 27(2), 444-454. DOI: 10.1002/csr.1838.

[13] Lichtenstein, D.R. Drumwright, M.E., \& Braig, B.M. (2004). The effect of corporate social responsibility on customer donations to corporate-supported nonprofits. Journal of Marketing, 68, 16-32. DOI: 10.1509/jmkg.68.4.16.42726.

[14] Malloy, D.C., \& Agarwal, J. (2003). Factors influencing ethical climate in a nonprofit organization: An empirical investigation. International Journal of Nonprofit and Voluntary Sector Marketing, 8(3), 224-250. DOI: $10.1002 /$ nvsm.215.

[15] Matten, D., \& Moon, J. (2008). "Implicit" and "Explicit" CSR: A conceptual framework for a comparative understanding of corporate social responsibility. Academy of Management Review, 33(2), 404-424. DOI: 10.5465/amr.2008.31193458.

[16] McWilliams, A., \& Siegel, D.S. (2001). Corporate social responsibility: A theory of the firm perspective. Academy of Management Review, 26(1), 117-127. DOI: 10.5465/amr.2001.4011987.

[17] Orlitzky, M., Schmidt, L.F., \& Rynes, S.L. (2003). Corporate social and financial performance: A metaanalysis. Organization Studies, 24(3), 403-441. DOI: 10.1177/0170840603024003910.

[18] Paine, L.S., Deshpande, R., Margolis, J.D., \& Bettcher, K.E. (2005). Up to code. Harvard Business Review, 83(12), 122-133.

[19] Saha, R., Cerchione, R., Singh, R., \& Dahiya, R. (2020). Effect of ethical leadership and corporate social responsibility on firm performance: A systematic review. Corporate Social Responsibility and Environmental Management, 27(2), 409-429. DOI: 10.1002/csr.1824.

[20] Scherer, A.G., \& Palazzo, G. (2011). The new political role of business in a globalized world: A review of a new perspective on CSR and its implications for the firm, governance and democracy. Journal of Management Studies, 48(4), 899-931. DOI: 10.1111/j.1467-6486.2010.00950.x.

[21] Schwartz, M. (2001). The nature of the relationship between corporate codes of ethics and behaviour. Journal of Business Ethics, 32(3), 247-262. DOI: 10.1023/A:1010787607771.

[22] Stojanovic-Aleksic, V., \& Boskovic, A. (2017). What really drives corporate social responsibility? Management: Journal of Sustainable Business and Management Solutions in Emerging Economies, 22(3), 75-87. DOI: 10.7595/management.fon.2017.0018.

[23] Supanti, D., Butcher, K., \& Fredline, L. (2015). Enhancing the employer-employee relationship through corporate social responsibility (CSR) engagement. International Journal of Contemporary Hospitality Management, 27(7), 1479-1498. DOI: 10.1108/IJCHM-07-2014-0319.

[24] Trong Tuan, L. (2012). Corporate social responsibility, ethics and corporate governance. Social Responsibility Journal, 8(4), 547-560. DOI: 10.1108/17471111211272110.

[25] Vitaliano, F.D. (2010). Corporate social responsibility and labor turnover. Corporate Governance: The International Journal of Business in Society, 10(5), 563-573. DOI: 10.1108/14720701011085544.

[26] Yaman, H.R., \& Gurel, E. (2006). Ethical ideologies of tourism marketers. Annals of Tourism Research, 33, 470-489. DOI: 10.1016/j.annals.2006.01.006.

[27] Yidong, T., \& Xinxin, L. (2013). How ethical leadership influence employees' innovative work behavior: A perspective of intrinsic motivation. Journal of Business Ethics, 116(2), 441-455. DOI: 10.1007/s10551012-1455-7.

[28] Peifer, J. L., \& Newman, D. T. (2020). Making the business case for corporate social responsibility and perceived trustworthiness: A cross stakeholder analysis. Business and Society Review, 125(2), 161-181. DOI: 10.1111/basr.12210.

[29] Sigurdsson, K., \& Candi, M. (2020). Saying and doing: Social responsibility declared and applied. Creativity and Innovation Management, 29(1), 128-140. DOI: 10.1111/caim.12340.

[30] Abugre, J. B., \& Anlesinya, A. (2020). Corporate social responsibility strategy and economic business value of multinational companies in emerging economies: The mediating role of corporate reputation. Business Strategy \& Development, 3(1), 4-15. DOI: 10.1002/bsd2.70. 
[31] McCandless, S., \& Ronquillo, J. C. (2020). Social equity in professional codes of ethics. Public Integrity, 22(5), 470-484. DOI: 10.1080/10999922.2019.1619442.

[32] Wang, Y., Xu, S., \& Wang, Y. (2020). The consequences of employees' perceived corporate social responsibility: A meta analysis. Business Ethics: A European Review, 29(3), 471-496. DOI: 10.1111/beer.12273.

Received: 2021-01-28

Revisions requested: 2021-03-20

Revised: 2021-03-23

Accepted: 2021-04-08

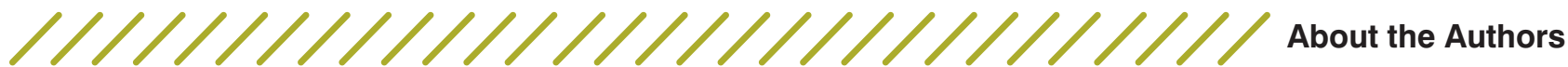

\begin{abstract}
Maja Mijatov
University of Novi Sad, Faculty of Sciences, Department of Geography, Tourism and Hotel Management, Serbia majamijatov@gmail.com; majam@dgt.uns.ac.rs
\end{abstract}

Maja Mijatov, PhD, is a Research Assistant at the Faculty of Sciences - Department of Geography, Tourism and Hotel Management (University of Novi Sad). Her main fields of interest are business ethics, corporate social responsibility, organisational behaviour, human resources, management. She is an author and co-author of different papers presented at the conferences and within different academic publications. Currently she is a member of the international project GLOBE 2020, as one of four researchers from Serbia, while she also was a member of the project approved by the Ministry of Education, Science and Technological Development of the Republic of Serbia.

Aleksandra S. Dragin University of Novi Sad, Faculty of Sciences, Department of Geography, Tourism and Hotel Management, Serbia sadragin@gmail.com; aleksandra.dragin@dgt.uns.ac.rs

Aleksandra Dragin, PhD, is a Full Professor at the Faculty of Sciences, University of Novi

Sad. Her research field includes human resources with specific interests in tourism, local communities, demographic transition and social responsibility activities. She published 198 scientific bibliographic units. She participated in numerous research activities, scientific conferences, seminars, round tables around the globe. She has participated as a member, expert, coordinator, reviewer or secretary in 24 projects. She is a member of the Commission for the 21 adoption of standards in the field of Tourism and related services at the Institute for Standardization of Serbia (ISO / TC 228).

\section{Vladimir Stojanović \\ University of Novi Sad, Faculty of Sciences, Department of Geography, Tourism and Hotel Management, Serbia vladimir.stojanovic@dgt.uns.ac.rs}

Vladimir Stojanović, PhD, is a Full Professor at the Faculty of Sciences (Department of Geography Tourism and Hotel Management), University of Novi Sad. He is a human geographer. His research field covers sustainable development in tourism, local communities in nature protection and ecotourism. He participated in numerous research activities, scientific projects, conferences, seminars. He is a member of the National Council for Tourism Development of the Republic of Serbia.
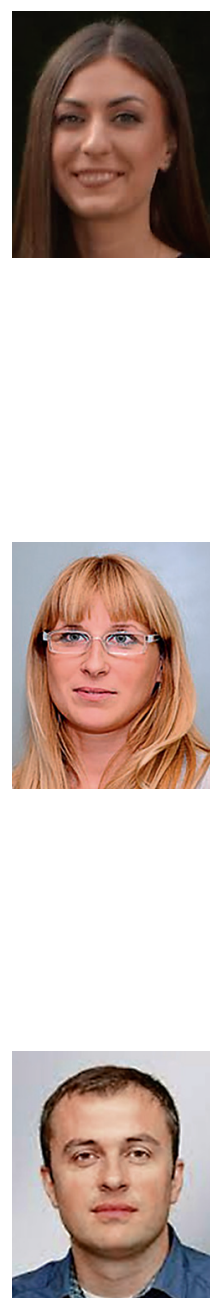


\author{
Anđelija Ivkov Džigurski \\ University of Novi Sad, Faculty of Sciences, Department of Geography, \\ Tourism and Hotel Management, Serbia \\ andjelija.ivkov@dgt.uns.ac.rs
}

Anđelija Ivkov Džigurski, PhD, is a Full professor and a chairman of the Chair of Social Geography at the Department of Geography, Tourism and Hotel Management, Faculty of Sciences (University of Novi Sad). She conducts research in Geography and Tourism

Geography and lectures in various geography and tourism subjects. From 2005 until today, Andjelija Ivkov-Džigurski has been a supervisor on 166 final papers (10 PhD dissertations). She is an author of 216 scientific papers, 15 books (1 student's book, 3 handbooks and 11 monographs) and 1 tourist guide. Since 2006 she organized, together with students, 49 charity events. She has been involved in 34 projects so far. Since 2007, she has been a Chairman of the Serbian commission for standards in tourism and related services (ISO/TC 228) at the Institute for standardization of Serbia.

\title{
Milena Nedeljković Knežević \\ University of Novi Sad, Faculty of Sciences, Department of Geography, Tourism and Hotel Management, Serbia milena.nedeljkovic@dgt.uns.ac.rs
}

Milena Nedeljković Knežević, PhD, is a Full Professor at the Faculty of Sciences,

University of Novi Sad. She obtained a PhD in Human resource management in 2009 at the Faculty of Technical Sciences, University of Novi Sad. She defended her second PhD dissertation in 2016, in the area of Behavioral economics at the Faculty of Economics and the Faculty of Philosophy (interdisciplinary), University of Novi Sad. Her research interests are within the area of management, management of human resources, organizational behaviour and entrepreneurship.

\section{Kristina Košić \\ University of Novi Sad, Faculty of Sciences, Department of Geography, Tourism and Hotel Management, Serbia kristina.kosic@dgt.uns.ac.rs}

Kristina Košić, PhD, is a Full Professor at the Faculty of Sciences - Department of Geography, Tourism and Hotel Management (University of Novi Sad). From October 2015 she has been a Chairman of Tourism at the Department of Geography, Tourism and Hotel management. Her main fields of interest are rural and spa tourism. She is an

author and co-author of different papers presented at the conferences and within different academic publications. She was a manager of the IPA project, but she also was a staff member within several research projects financed by the Ministry of Science or other Serbian Institutions.
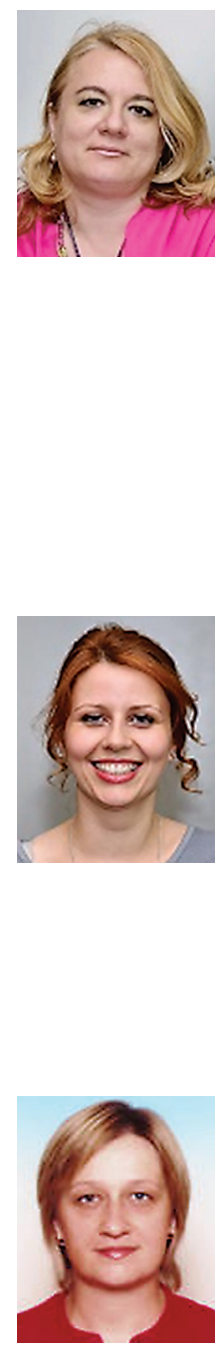